\title{
TRADE, REVENUE AND WELFARE EFFECTS UNDER AN ECONOMIC PARTNERSHIP AGREEMENT BETWEEN BURKINA FASO AND THE EUROPEAN UNION
}

\author{
G.O. Onogwu, Researcher \\ Department of Agricultural Economics; Federal University Wukari, Nigeria \\ E-mail: gonogwu@yahoo.com.sg \\ C.J. Arene, Researcher \\ Department of Agricultural Economics, University of Nigeria, Nigeria \\ E-mail: cjarene@yahoo.com
}

\begin{abstract}
This study estimates the impact on Burkina Faso of eliminating tariffs on imports from the EU under EPAs, considering trade, revenue and welfare effects. At complete elimination of tariffs on all products imports from trade classification sections (TDC 01-13) from the EU. Burkina Faso is likely to experience both welfare gains and losses depending on the values of imports of each trade classification section in question. The overall welfare effect relative to GDP tends to be very small and positive, but potential tariff revenue losses are enormous even when the country has up to fifteen - twenty-five years in which to implement the tariff reductions, unless with scope for tax substitution. EPAs effects are concentrated on those product sections where trade creation outweighs trade diversion such as Animal products, Vegetable products, Animal/Veg. products, Mineral products, and Textiles products. Besides, product sections with the greatest market opportunities for EU suppliers to displace any of the other suppliers, ECOWAS and/or ROW include sections where trade diversion outweighs trade creation effects, such as prepared foodstuffs, product of chemicals, plastics, raw hides \& skin, etc. The sensitive products (SPs) to be excluded from tariff removal should include sections in which ECOWAS member nations are suppliers to regional importers so that excluding them as SPs would improve the welfare gain compared to estimates where tariff are removed from those products in which ECOWAS have zero potential. The results at this level of aggregation will provide useful information to the on-going negotiations between ECOWAS and the EU in determining Burkinabe's products to be exempted from tariff removal during EPAs based on the severity of the effects on varied trade classification (TDC) sections, among other considerations.
\end{abstract}

\section{KEY WORDS}

Trade; Revenue; Welfare; Economic Partnership Agreements; Burkina Faso; European Union.

The Economic Partnership Agreements (EPAs) are set out to help West African countries integrate into the world economy and share in the opportunities offered by globalization. The provision of scope for wide-ranging trade co-operation on areas such as services, cum standards acting as drivers of change to kick-start reform and help strengthen rule of law in the economic field, would attract foreign direct investment (FDI), to help create a "virtuous circle" of growth (http://ec.europa.eu/trade/wider-agenda/development/economicpartner).

In West Africa, the current status of EPAs is that two West African countries, Côte d'Ivoire and Ghana, initiated bilateral "stepping stone (or "interim") EPAs" with the European Union (EU) at the end of 2007. The interim EPA with Ivory Coast (Côte d'Ivoire) was signed on 26 November 2008. The interim EPA with Ghana has not been signed. The two agreements have not been ratified. However, the latest was the European Union and West African negotiators meeting in Accra, Ghana, at technical level from 15 to 18 November 2011, which discussed the way ahead in the regional Economic Partnership Agreement (EPA) talks. Progress was made in particular on the text of the agreement and the EPA Development Programme (PAPED), work continues on issues including West Africa's market access offer. The next steps were that the regional agreement currently negotiated will cover 
goods and development-cooperation and include rendezvous clauses for services and rules chapters. Next round include a session on rules of origin on February $6-10,2012$, followed by a meeting at technical and Senior Official level scheduled for February $13-17,2012$, both of them in Brussels. The light version of the original EPAs has not put an end to the negotiations as some of the countries would like to see the terms of the trade agreement revised, or their scope extended, and conclude the agreements at a regional level, to preserve their regional integration process (ECDPM, 2012).

Recently, Europe threatened to withdraw the special trade preferences by 2014 to countries not showing commitment to proceed with their interim EPA. Europe's objective hopefully is to press for the conclusion of broader trade deals at regional level that would replace these awkward and controversial interim EPAs. In an apparently generous move, the European parliament's trade committee called on decision-makers to extend this deadline to 2016. The identification of regionally traded products/markets in a bid to sustaining them through joint and diversified action plan by the region is very necessary in aiding the negotiations through listing of products where trade exist among the Economic Community of West African States( ECOWAS) regional partners (sensitive products). As negotiations allow for the exclusion of sensitive products and for phased introduction of the tariff reductions, Burkina Faso and indeed the entire ECOWAS regions may benefit by treating products currently traded among the members of the region as sensitive for EPAs, hence avoiding or postponing any reductions on tariffs on their imports from the EU. More so, from the trade data, there is no evidence of supplies from ECOWAS member nations of products from trade sections (TDC14-21) corresponding to HS Chapters 71-97. Put differently, the EU could provide 'aid for regional trade' and support for measures that enhance the productivity and competitiveness of domestic producers, for export capacity (both intra- and extra-regional) to improve. The remainder of the paper is organized as follows. Section 2 discusses some of the existing theoretical and empirical literatures. Section 3 presents the analytical methodology, while section 4 provides estimates covering 13 trade classification sections aggregated for the purpose of reporting.

Table 1. Structure of Trade between Burkina Faso and the EU by Products

(\% of Exports and Imports from EU of Various products, 2011)

\begin{tabular}{|c|c|c|c|c|c|c|}
\hline TDC & Exports & Share of Total & TDC & Import & Share of Total & EU Trade \\
\hline Sections & to $\mathrm{EU}(€)$ & Export to Eu(\%) & Sections & from $E U(€$ & Import from EU(\%) & Balance w \\
\hline TDC 02 & 19 & 29.2 & TDC 16 & 179 & 36.6 & 178 \\
\hline TDC 14 & 18 & 28.3 & TDC 06 & 69 & 14.1 & 69 \\
\hline TDC 11 & 16 & 25.8 & TDC 04 & 52 & 10.6 & 51 \\
\hline TDC 08 & 3 & 4.4 & TDC 17 & 51 & 10.5 & 51 \\
\hline TDC 03 & 2 & 3.5 & TDC 15 & 24 & 4.8 & 23 \\
\hline TDC 05 & 1 & 2.2 & TDC 02 & 23 & 4.7 & 5 \\
\hline TDC 15 & 1 & 1.1 & TDC 07 & 17 & 3.4 & 16 \\
\hline TDC 04 & 1 & 1 & TDC 18 & 13 & 2.6 & 13 \\
\hline TDC 16 & 0 & 0.5 & TDC 01 & 12 & 2.5 & 12 \\
\hline TDC 17 & 0 & 0.3 & TDC 11 & 10 & 2.1 & -6 \\
\hline TDC 09 & 0 & 0.2 & TDC 05 & 8 & 1.7 & 7 \\
\hline TDC 21 & 0 & 0.2 & TDC 10 & 8 & 1.6 & 8 \\
\hline TDC 18 & 0 & 0.2 & TDC 20 & 6 & 1.1 & 5 \\
\hline TDC 20 & 0 & 0.1 & TDC 13 & 5 & 1.1 & 5 \\
\hline TDC 06 & 0 & 0 & TDC 19 & 1 & 0.2 & 1 \\
\hline TDC 07 & 0 & 0 & TDC 12 & 1 & 0.2 & 1 \\
\hline TDC 13 & 0 & 0 & TDC 03 & 0 & 0 & -2 \\
\hline TDC 10 & 0 & 0 & TDC 14 & 0 & 0 & -18 \\
\hline TDC 01 & 0 & 0 & TDC 08 & 0 & 0 & -3 \\
\hline TDC 12 & 0 & 0 & TDC 09 & 0 & 0 & 0 \\
\hline TDC 19 & 0 & 0 & TDC 21 & 0 & 0 & 0 \\
\hline
\end{tabular}

Source: EUROSTAT (Comext, Statistical regime 4); World excluding Intra-EU trade and EU27. 
It is evident from table 1 above that the major exports of Burkina Faso to the EU include Vegetable products; Natural or Cultured pearls; precious or semi-precious stones; and Textiles and textile articles, corresponding to trade classification sections 02,14 and 11 , respectively, among others. Besides, data (in table 1 above) reveals that the major import products from the EU are Machinery and mechanical appliances, Products of the chemical or allied industries, Prepared foodstuffs; Beverages, spirits and vinegar; tobacco, and Vehicles, aircraft, vessels and associated transport equipment, i.e. trade classification sections 16, 06, 04, and 17, respectively. Others include base metals and articles of base metal, Vegetable products, Plastics and articles thereof; rubber and articles thereof, Optical photographic, cinematographic, measuring, checking precision etc., Live animals; animal products, Textiles and textile articles, mineral products, pulp of wood or other fibrous cellulose material; paper or paperboard etc., corresponding to trade classifications 15, 02, 07, 18, 01, 11, 05, 10 etc., respectively.

Table 2. Patterns Of Imports By Burkina Faso From Three Regional Sources (in millions of Dollars)

\begin{tabular}{|l|l|r|r|r|r|r|r|r|r|}
\hline Burkina Faso & TDC & Imports & \% Share & \multicolumn{1}{l}{ From } & \% Share & From & \% Share & World \\
\hline HS Description & Sections & from EU & of Imports & ECOWAS of Imports & ROW & of Imports Total \\
\hline Animal Products & TDC 01 & 8789.857 & $\mathbf{3 6 . 3 8}$ & 3504.782 & 14.05 & 11868.35 & 49.12 & 24163.04 \\
\hline Veg. Products & TDC 02 & 34555.12 & 26.75 & 20205.83 & 15.64 & 74417.37 & $\mathbf{5 7 . 6 1}$ & 129173.3 \\
\hline Anima//Veg Products TDC 03 & 368.761 & 1.96 & 14237.75 & 75.54 & 4240.959 & 22.5 & 18847.47 \\
\hline Prep foodstuffs etc. & TDC 04 & 25177.42 & $\mathbf{1 7 . 4 7}$ & 77189.81 & 53.57 & 41717.87 & 28.95 & 144085 \\
\hline Mineral Products & TDC 05 & 178110.8 & 32.8 & 279179.6 & 51.42 & 85698.22 & 15.78 & 542988.6 \\
\hline Prod. of Chemicals & TDC 06 & 82968.01 & $\mathbf{3 1 . 7 4}$ & 70006.51 & 26.79 & 108385.1 & 41.47 & 261359.6 \\
\hline Plastics and Articles & TDC 07 & 17361.76 & 19.89 & 30148.52 & 34.53 & 39798.11 & 45.58 & 87308.39 \\
\hline Raw hides and Skins & TDC 08 & 269.865 & 16.55 & 240.248 & 14.73 & 1120.809 & 68.72 & 1630.922 \\
\hline Wood \& Articles of & TDC 09 & 253.921 & $\mathbf{3 . 4 6}$ & 6484.03 & 88.27 & 607.478 & 8.27 & 7345.429 \\
\hline Pulp of Wood etc. & TDC 10 & 10822.88 & 23.43 & 10439.79 & 22.6 & 24927.19 & 53.97 & 46189.85 \\
\hline Textiles \& Articles & TDC 11 & 11649.68 & 18.85 & 4678.128 & 7.57 & 45476.2 & 73.58 & 61804.01 \\
\hline Footwear, Headgear & TDC 12 & 864.908 & 11.33 & 2400.281 & 31.44 & 4369.268 & 57.23 & 7634.457 \\
\hline Articles of Stone etc & TDC 13 & 2132.224 & 25.26 & 971.674 & 11.51 & 5337.611 & 63.23 & 8441.509 \\
\hline
\end{tabular}

Source: Computed by the Authors from UNCOMTRADE Import Data, 2010.

The products in which Burkina Faso will likely experience displacement effects include those where she imported up to $25 \%$ share from the EU and the ECOWAS regional import share is at least $7 \%$ (see Table 2 above). The table shows that displacement effects will be possible in products such as Animal products, Vegetable products, Mineral products, products of chemicals, pulp of wood etc., and articles of stone etc in which regional import shares were over $7 \%$ of the total product imports of the trade classification sections. Besides, trade diversion effects occurred where the EU shares were within 10 percent points of the rest of the World (ROW) share as in Animal/Vegetable products, prepared foodstuffs, products of chemicals, and wood and articles of wood.

The introduction of reciprocity under EPAs will tend to threaten Burkinabe's intraECOWAS trade for a number of reasons. First, there is a direct displacement threat to existing regional suppliers from the elimination of the external tariff protection vis-à-vis European exporters. There is also an indirect threat associated with the displacement of domestic production by European exporters in domestic markets, which may thereby reduce regional production capacity and future prospects for intra-regional exporting. These threats to Burkina Faso's trade development can be offset in a number of ways. Most obviously, as negotiations allow for the exclusion of sensitive products and for phased introduction of the tariff reductions, Burkina Faso and indeed other ECOWAS member nations are most likely to benefit by treating products traded within the region as sensitive for EPAs, hence avoiding or postponing any reductions in tariffs on imports of such products from the EU. Less directly, to the extent that the EU provides 'aid for Burkina Faso's trade' and support for measures that enhance the productivity and competitiveness of the nations producers culminating to 
improved intra- and extra-regional export capacity. If EPAs promote increased Burkina Faso and ECOWAS exports to the EU there is potential to benefit from spill-over (Chris Milner, Oliver Morrissey and Evious Zgovu, 2009).

The EPAs are both based on and aimed at the process of integration and regional cooperation already embarked upon by the ECOWAS countries, thus promoting intraECOWAS trade with a view to stimulating their integration into the world economy. The expectation that these objectives can be achieved is a major problem. Will they be compatible with development needs in Burkina Faso and other ECOWAS countries? Will the EPAs be sufficiently flexible in their design to enable Burkina Faso and other ECOWAS countries to adapt? Are the countries themselves ready for such wide-ranging negotiations? Who, which products will really benefit from the EPAs? Will all traded products within the ECOWAS markets be regarded as sensitive and as such exempted from tariff removal?

This paper estimates the trade, welfare and revenue effects on Burkina Faso of embarking on free trade under an economic partnership agreements between ECOWAS and the EU, focusing on static effects.

The specific objectives of the study include to: (1) Describes the patterns of product imports of Burkina Faso from EU, ECOWAS, and the rest of the World (ROW); and (2) Estimates the likely trade, revenue, and welfare among other associated effects on Burkina Faso of embarking on free trade with the EU under an ECOWAS-EU Economic Partnership Agreements.

\section{THEORETICAL AND EMPIRICAL ISSUES OF EPAS}

On West African side, EPAs negotiations were led by commissions of ECOWAS and UEMOA. ECOWAS is an organization of 15 countries seeking to promote regional economic integration and establish a functioning customs union. On the other hand, UEMOA is a monetary union of 8 ECOWAS members (Benin, Burkina Faso, Ivory Coast, Mali, Niger, Senegal, Togo and Guinea-Bissau). Its currency, the CFA-Franc, is issued by the UEMOA central bank (BCEAO), which is supported by the French Treasury and is fixed against the euro. Their EPAs negotiations are focused on:

strengthening regional integration;

- prioritizing development and enhancing the region's development program (PAPED);

- enhancing competitiveness (e.g. capacity-building for West African companies and exporters);

- integrity of agricultural sector;

- alternative funding for net transitional and tax offsetting costs;

- inclusion of a regional list for sensitive West African products.

Two West African countries, Côte d'Ivoire and Ghana, initialed bilateral "stepping stone (or "interim") EPAs" with the EU at the end of 2007. The interim EPA with Ivory Coast (Côte d'Ivoire) was signed on 26 November 2008. The interim EPA with Ghana has not been signed. The two agreements have not been ratified. European Union and West African negotiators met in Accra, Ghana, at technical level from 15 to 18 November 2011, to discuss the way ahead in the regional Economic Partnership Agreement (EPA) talks. Progress was made in particular on the text of the agreement and the EPA Development Program (PAPED), work continues on issues including West Africa's market access offer. The Interim EPAs which were signed with Ivory Coast (Côte d'Ivoire) and initialed with Ghana cover the following:

- duty and quota-free EU market access;

- gradual liberalization (removal of duties and quotas) over 15 years for $81 \%$ of EU imports to Ivory Coast (Côte d'Ivoire) and $80 \%$ to Ghana;

- EU exports are mainly industrial goods, vehicles and chemicals which do not compete with domestic production;

- safeguard provisions enabling both countries to protect fragile economic sectors by re-introducing quotas or duties; 
- agreement to foster cross-border trade within the region (e.g. more efficient customs procedures);

- EU support to help local companies become more competitive and meet EU import standards.

Among the welfare gains from free international trade is the static gain from trade, which increases economic well-being of a country and its region by holding resources and technology constant. This leads to consumption and production gains. Even though production may remain fixed, the opportunity to trade at world prices leads the consumption point to a higher consumption indifference curve. These gains come about because productive resources are channeled into the region's comparative advantage industries; and because of this redistribution of resources, overall output (GDP) rises, leading to the static production well-being from trade.

Morrissey and Zgovu (2005) estimated the impact on a sample of 36 ACP countries of eliminating tariffs on agricultural imports from the EU under EPAs, considering trade, welfare and revenue effects. In their results, even assuming 'immediate' complete elimination of all tariffs on agriculture imports from the EU, and when excluding up to $20 \%$ of imports as sensitive products, over half of ACP countries are likely to experience welfare gains. However, although most LDCs gain (10 out of 13), most non-LDCs (about 60\%) lose. The overall welfare effect relative to GDP tends to be very small, whether positive or negative. While potential tariff revenue losses are no negligible, given that countries have at least ten years in which to implement the tariff reductions, there is scope for tax substitution. They opined that an important issue is identifying the sensitive products (SPs) to be excluded, and that excluding SPs reduced the welfare gain (or increased the welfare loss) compared to estimates where no products are excluded.

\section{ANALYTICAL FRAMEWORKS}

The partial equilibrium analytical framework used by Morrissey and Zgovu (2011) and McKay et al (2005) were extended to the established theoretical framework for analyzing the economic (welfare) effect of regional integration (e.g., Balassa, 1974; Lyakurwa et al., 1997; Schiff and Winters, 2003) as applied by Panagariya (1998) to consider when Burkina Faso integrate with large countries such as EU given her ECOWAS regionally traded products.

Figure 1 illustrates the welfare effects of Free Trade Area arrangements for the case of Burkina Faso (bf) of an initial regional group, ECOWAS.

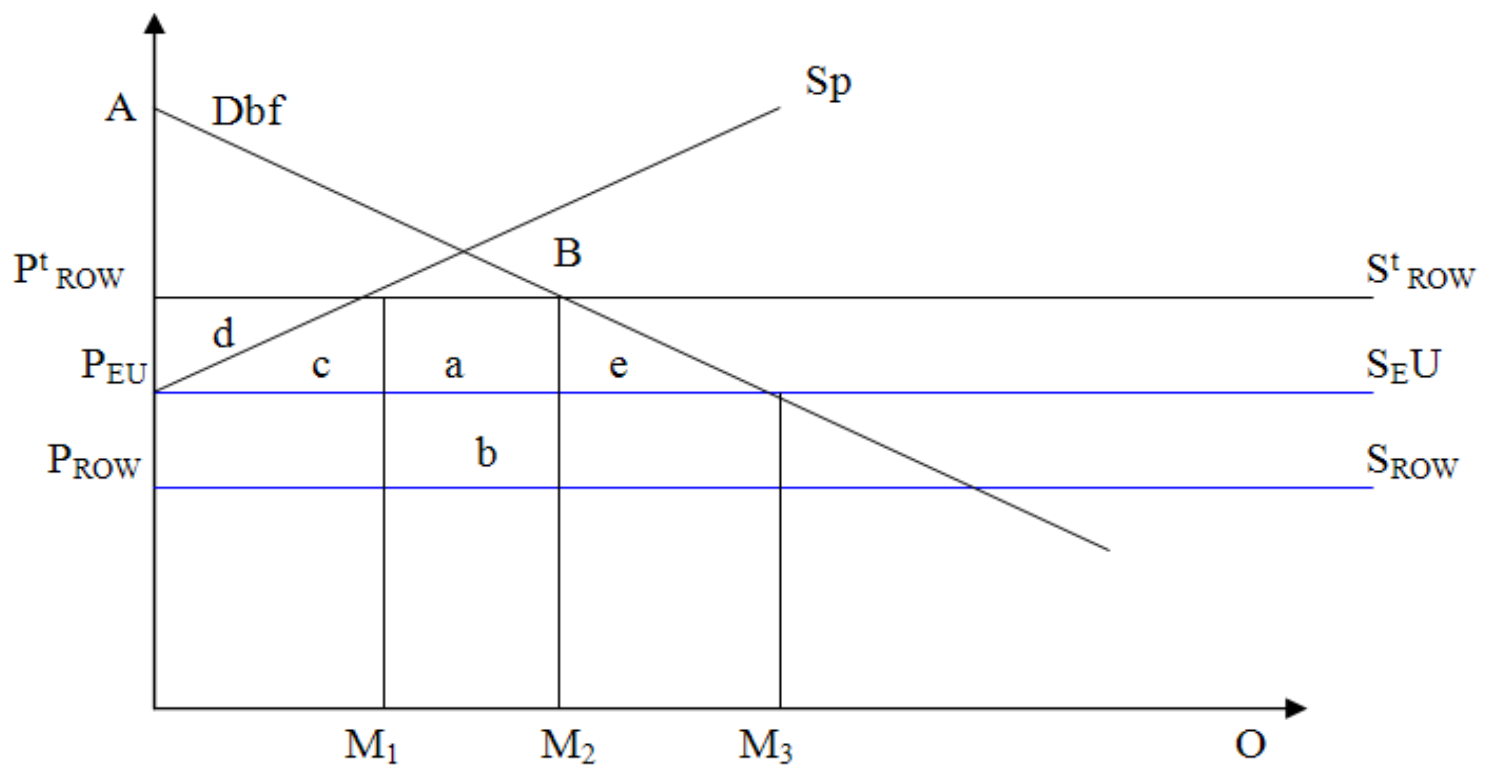

Figure 1. Effect of Free Trade Area between Burkina Faso and EU under EPAs 
The partner country's $(\mathrm{P})$ supply curve is upward sloping and the supply for two (initial) outside suppliers (here the EU and the rest of the world - ROW) is assumed to be infinitely elastic. The analysis is partial equilibrium in nature and markets are assumed to be perfectly competitive with perfect substitutability between imported and domestically produced import substitutes. Assume that bf and P have already formed a PTA, and as small developing country can be viewed jointly as being small relative to the EU and ROW who supply at constant cost ( $P_{E U}$ and $P_{R O W}$ respectively). In the case of figure 1, we assume for the sake of detailed description that $P_{E U}>P_{R O W}$, therefore subsequent discriminatory trade policies by the FTA towards the outside countries can have both trade creating and diverting effects.

$D b f$ represents Burkina Faso's demand for imports, $S_{P}$ the partners' supply of exports, and $S_{E U}$ and $S_{R O W}$ are the respective export supply functions for the two outside country groupings. We start with a FTA and a non-discriminatory (ad valorem) tariff $(t)$ on extra-regional imports (where $P^{t}{ }_{\text {ROW }}=P_{\text {ROW }}(1+t)$ but $P^{t}{ }_{E U}$ is not shown in the case of the higher cost EU supplier). The home country imports $O M_{2}$ in total, with $O M_{1}$ coming from the partner country and $M_{1} M_{2}$ from the rest of the world (ROW). By ruling out domestic production capability we can define welfare $(W)$ by reference to consumer surplus with respect to the import demand function, $D b f$. The $W_{F T A}$ for each home country is given by the triangle $A B P^{t}{ }_{R O W}$ plus the tariff revenue on extra-regional imports (area $a+b)$. Now assume that the FTA introduces a discriminatory tariff policy towards extra-regional countries, and as a result of EPAs with the EU continues to impose tariff $t$ on imports from ROW but allows imports from the EU in duty free. The relevant supply price is now PEU, with the total quantity of imports expanding from $\mathrm{OM}_{2}$ to $\mathrm{OM}_{3}$ and imports coming now wholly from the EU. There are strictly three components of this trade-effect of the EPAs; a consumption expansion effect $M_{2} M_{3}$, a 'trade diversion' effect $M_{1} M_{2}$, and a 'trade creation' effect $O M_{1}$. The last two of these effects need more careful explanation, however. In the case of standard PTA analysis trade diversion usually relates to diverting trade from more efficient extra-regional suppliers to less efficient intra-regional suppliers. The EPAs, however, diverts between extra-regional suppliers; $M_{1} M_{2}$ is imported from the less efficient EU rather than the ROW. The resource cost of this is represented by the area $b$, with total tariff revenue lost by the home country being area $(a+b)$. Similarly, in terms of standard FTA analysis, trade creation usually describes the displacement of less efficient home production by globally efficient extra-regional production. In this case, however, the EPAs involves the replacement of intra-regional imports by more (but here not globally) efficient extra-regional imports from the EU. The global resource-saving on this 'tradecreation' (or trade source substitution) effect is shown by area $c$ in Figure 1 above. This and the loss in producer surplus for partner country exporters (area $d$ ) allow consumer surplus on this component of the trade effect of the EPAs to increase by area $(c+d)$. Thus, the welfare implications for the home country of shifting from the FTA to the EPAs are ambiguous, the consumption and trade-creation effects increasing welfare and the trade-diverting effect reducing welfare i.e. $\Delta W=(c+d+e)-b$. Clearly the more efficient is the EU the smaller the costs of trade-diversion and the greater the probability of a welfare-improving EPA. Indeed in the extreme as $S_{E U} \rightarrow S_{R O W}$ then the EPAs tends toward the free trade outcome (Mckay et el 2005).

Consumption Effects. In estimating the effects, we began with the trade data and allocated imports by product/product sections into one of three cases (EU, ECOWAS, and $\mathrm{ROW}$ ). In those products where the EU is globally efficient and therefore the dominant supplier to a particular ECOWAS market prior to the formation of the EPAs, we assume that only consumption effects would follow from the EPAs. In terms of Figure 1, this is equivalent to assuming that $S_{R O W}$ lies above $S_{E U}$ and that there is no competitive regional supply 
capability. Thus, for those products where the EU is the dominant supplier we estimated the consumption effect alone $\Delta C^{M}$.. relative to the existing EU import levels as follows:

$$
\Delta C^{M}=\left(\frac{t}{1+t}\right) \cdot \ell^{d}{ }_{M} \cdot M_{0}^{E U}
$$

where $t$ is the MFN tariff rate imposed on imports from the EU in the present period $n, \ell^{d}$ is elasticity of demand for imports, and $M_{O}{ }^{E U}$ is imports from EU.

Trade diversion' with consumption effects. Cases of trade diversion considered where when more efficiently produced imports from the ROW are displaced by relatively less efficiently produced commodities from the EU due to EPAs. Product sections for which the ROW is a dominant supplier pre-EPA can be taken to indicate that the ROW is more efficient than the EU, but as EPAs lead to $P_{E U}<P^{t}{ }_{R O W}$ under the prevailing constant production cost conditions the EU becomes the sole supplier to country $j$, and total import diversion will be the upper limit of trade diversion. However, logically, not all imports will be diverted from ROW, and we assumed that the EU must initially be supplying a reasonable share of imports of a product (at least $20 \%$ ) to have a capacity for trade diversion.

The consumption effects due to trade diversion $\left(\Delta M^{T D}\right)$ were estimated in a similar way by assuming that on average the post-EPA price of imports from the EU would lie midway between $P_{R O W}$ and $P^{t}{ }_{R O W}$. This is by:

$$
\Delta M^{T D}=(1 / 2) \cdot\left(\frac{t}{1+t}\right) \cdot \eta_{M}^{\partial} \cdot M_{O}^{R O W}
$$

where $M_{O}{ }^{R O W}=$ Current quantity of imports from ROW.

Trade Creation with Consumption Effects. For those Products where other ECOWAS countries provide greater than $25 \%$ of imports we estimated the effects of trade creation with consumption just as the trade diversion case. Here, the assumption is that the $\mathrm{EU}$ is a more efficient supplier than the rest of the world. If the duty free supply price from the ECOWAS lies over the relevant range between $P^{t} R O W$ and $P_{E U}$, then all of the current imports from the ECOWAS to the home country will be replaced by more efficient production from the EU. Thus the maximum value of the trade created. $\Delta M^{T C}$..for the EU by this deflection from ECOWAS sources were estimated by:

$$
\Delta M^{T C}=1 / 2 \cdot\left(\frac{t}{1+t}\right) \cdot \eta^{d} M \cdot M_{0}^{\text {ECOWAS }}
$$

where $M_{0}{ }^{\text {ECOWAS }}$ is the current value of imports from ECOWAS.

The tariff revenue loss on imports from EU and Welfare effects were estimated thus:

$$
\begin{gathered}
\Delta R^{C}=-t \cdot M_{O}{ }^{E U} \\
\Delta W^{C}=(1 / 2) t \cdot \Delta M^{C}
\end{gathered}
$$

\section{ESTIMATING TRADE, REVENUE AND WELFARE EFFECTS}

The methodology set out in Section 3.0 was used to estimate trade, revenue and welfare effects of an ECOWAS-EU proposed EPAs on Burkina Faso. Given data availability, 
detailed analysis was possible for Burkina Faso. Tariff data were sourced from the Trade Analysis and Information System (TRAINS), United Nations Conference on Trade and Development (UNCTAD) online source at the six-digit level of the HS. The Most Favored Nation (MFN) Tariff data at six-digit level of HS and import demand elasticities were taken from TRAINS. Other data sources include ECOWAS Social and Economic Indicators cum ECOWAS Statistical Bulletin; Statistical Offices of ECOWAS member nations, African Statistical Yearbook, International Monetary Fund (IMF), and the World Bank among others. The import data were obtained from UNCOMTRADE statistics at the Six-digit level of the Harmonized System (HS). Aggregated across categories and economies were to obtain ECOWAS-ECOWAS, ECOWAS-EU and ECOWAS-ROW import values. All the data are in millions of $\$$ US.

The Trade Effects. The value of trade effects due to consumption, trade diversion, trade creation and the corresponding revenue and welfare effects were obtained for Burkina Faso's move for EPAs. It is evident from the trade data that Burkina Faso among other ECOWAS countries dominated intra-ECOWAS suppliers by accounting for 16.57 percents of the intra-regional imports.

Trade Classification Sections (TDC) Effects. Below is a detailed products estimate for Burkina Faso. The products where major potential trade effects occur were indicated by these relatively detailed section results, so as to x-ray the potential adjustment implications of EPAs. From the result in table 3, welfare losses will be less for product sections such as Animal products, mineral products, Textiles and Articles of stone with almost zero tariff revenue effect. EPAs effects are concentrated on those product sections where trade creation outweighs trade diversion as in Animal products, Vegetable products, Animal/Veg. products, Mineral products, and Textiles products. Here local producers may anticipate greater import competition and/or increased competition from EU suppliers and so should be exempted from tariff removal. Other product sections where there will be the greatest market opportunities for EU suppliers to displace any of the other suppliers ECOWAS and /or ROW include sections where trade diversion outweighs trade creation effects, such as in prepared foodstuffs, product of chemicals, plastics, raw hides \& skin, etc. To sustain trade and deepen regional integration among ECOWAS countries, tariff removal should be avoided in these products as well.

Table 3. Burkina Faso: Product Sections Effects (in millions of Dollars)

\begin{tabular}{|l|l|r|r|r|r|r|}
\hline Country: B. Faso & TDC & CE & TD \& CE TC \&CE & Revenue & Welfare \\
\hline & Sections & & & & Effect & Effect \\
\hline HS Description & & & & & & \\
\hline Animal Products & TDC 01 & 9.72 & 1.87 & 15.25 & -4.9 & 0.53 \\
\hline Veg. Products & TDC 02 & 77.53 & 27.14 & 76.45 & -35.43 & 6.86 \\
\hline Anima/Veg Product: TDC 03 & 452.05 & 1761.91 & 2243.74 & -488.01 & 2118.98 \\
\hline Prep foodstuffs etc. & TDC 04 & 282.77 & 91.16 & 17.22 & -75.21 & 28.28 \\
\hline Mineral Products & TDC 05 & 21.94 & 6.32 & 171.94 & -22.31 & 0.55 \\
\hline Prod. of Chemicals & TDC 06 & 110.4 & 36.11 & 3.8 & -64.93 & 2.76 \\
\hline Plastics and Articles & TDC 07 & 74.46 & 227.45 & 150.37 & -53.4 & 1.86 \\
\hline Raw hides and Skins TDC 08 & 16.41 & 120.85 & 35.25 & -14.67 & 1.63 \\
\hline Wood \& Articles of & TDC 09 & 30.53 & 4959.71 & 131.81 & 0 & 150.02 \\
\hline Pulp of Wood etc. & TDC 10 & 40.67 & 377.67 & 2.23 & -44.53 & 2.29 \\
\hline Textiles \& Articles & TDC 11 & 1.4 & 19.42 & 34.56 & 0 & 0.12 \\
\hline Footwear, Headgear TDC 12 & 40.37 & 451.79 & 376.42 & -50.3 & 4.04 \\
\hline Articles of Stone etc TDC 13 & 9.15 & 98.21 & 19.04 & -7.7 & 0.51 \\
\hline
\end{tabular}

Source: Authors' estimation using UNCOMTRADE Import Data, 2010.

Tariff Revenue and Welfare Effects. Imports from the EU are expected to increase remarkably for Burkina Faso due to trade creation, diversion and consumption effects, while 
tariff revenue would fall as a result of the increase in duty-free imports from EU. The consumer as well as national welfare would increase as a result of trade creation and consumption effects, but due to potentially large costs of trade diverted from efficient ROW sources, the net welfare in Burkina Faso are likely to fall as a result of this static trade effects of Burkina Faso-ECOWAS-EU EPAs.

The revised range estimates were where the scope for trade creation from ECOWAS and diversion from the ROW to the EU may be restricted not by limited EU supply capability or competitiveness, but protection (exclusion as sensitive products). The product sections (HS chapters 71-97) where EU exports to ECOWAS are relatively large with ECOWAS having little or zero potentials were excluded from the estimation procedure, giving rise to reduced regional revenue and welfare effects, given that products considered are those that ECOWAS, EU, and ROW currently have the potentials to export.

Assessing the Effects on Burkina Faso. Trade data available in TRAINS enabled the application of the empirical method for the Burkina Faso. Her pattern of imports from the EU, ECOWAS and ROW for various trade classification sections varied in term of values. However, the levels for the expansion of imports from the EU following EPAs culminating to consumption and trade diversion effects from the rest of the world, with corresponding net welfare losses were evident. Trade diversion with consumption effects did not dominate positive trade creation with consumption effects in Burkina Faso. This implies that there would be large scope for 'trade creation' displacement of Burkina Faso exports to ECOWAS by EU given the limited existing penetration of the ECOWAS markets by countries such as Cape Verde, Nigeria, and Senegal suppliers, especially for products where displacement by EU suppliers is eminent. Therefore, producers in Burkina Faso would likely gain import share from ECOWAS member nations, which may be offset with increased imports from the EU if not taken care of during EPAs negotiations by treating these products as sensitive.

\section{APPLICATIONS TO PRODUCT IMPORTS FROM EU, ECOWAS \& ROW}

The static effects of ECOWAS-EU EPAs on Burkina Faso were considered. Specifically, trade, revenue and welfare impacts on Burkina Faso of embarking on EPAs were considered. The net welfare effects were positive for Burkina Faso due to her relative imports from the EU compared to the rest of the world and local imports of various trade classification sections. Trade creation were more than trade diversion in trade classification sections such as Animal products, Vegetable products, Mineral products and Textile products, implying improved welfare if these sections will be exempted from tariff removal. More so, the tariff revenue losses on the trade sections are relatively low. The allocation of import values into the various sources were in accordance with retrieved import data trade classification sections. Given the current levels of imports from these sources and securing exemption of traded products from HS 71-97, the net effect is not likely to be adverse on Burkina Faso. These points out to the need for Burkina Faso and indeed other ECOWAS countries to consider the 15 to 25 years to open up to EU imports while providing protection for the sensitive $20 \%$ of imports of products within HS 01-70 chapters where other member nations are suppliers. The current trade flow pattern in various trade classification sections within the sub region should be sustained to allow for competiveness, healthy intra-ECOWAS trade cum deepened integration of the region through trade. Trade liberalization measures to be undertaken by ECOWAS countries are best for product sections where they have little or no potentials to produce as evident in the trade flow pattern. This in turn may bring significant benefits in terms of increased domestic and foreign investment in Burkina Faso as a compensatory move for revenue losses, given the trade gains the EU will enjoy. Hopefully, the rest of the world who would lose their market share are likely to set up some measures similar to partnership arrangements, aimed at maintaining their market grip and this could significantly change the welfare implications of the partnership agreement with the EU. In conclusion therefore, since the welfare effect is negative for Burkina Faso, but exempting the current regionally traded product sections from tariff removal should be taken into account in negotiating the EPAs. 


\section{CONCLUSIONS AND POLICY IMPLICATIONS}

The analyses were conducted at six-digit HS level of disaggregation. Partial Equilibrium Methodology was employed in this study to estimate the potential trade, tariff revenue and welfare implications for Burkina Faso of accepting to liberalize substantially on a wide range of products imports including those where regional members are suppliers from the EU in an EPA. The results at this level of aggregation will provide useful information to the on-going negotiations between ECOWAS and the EU in determining the products to be exempted from tariff removal during EPAs based on the severity of the effects on product sections, among other considerations.

The study's major conclusions are that the EPA induced import increases will likely add to the pressure in the industries in Burkina Faso, which have already been subjected to prolonged episodes of unilateral liberalization (under the structural Adjustment Programme) and regionalization (regional integration). Interestingly there are products in which Burkina Faso has low potential to develop competitive production to meet regional demand and forge ahead for extra-regional exports. The country is likely to record increases in total imports over the existing levels, and there will be significant import substitution away from the relatively least cost producers in the rest of the world to EU producers leading to trade diversion. The need to postpone tariff removal on those products/product sections where Burkina Faso is the major supplier is, therefore, very necessary and should be adopted during the negotiations. Unless the product sections traded by nation are provided support to start/improve production and realize increasing exports, the potentials may be undermined subsequently by strong competition when EPAs becomes operational. So, measures to include this should be spelt out in EPAs.

Furthermore, the study finds that fiscal reforms to replace EPAs induced tariff revenue losses are needed. Examples of non-tariff instruments that may assume greater importance in revenue generation include value-added tax (VAT) and excise taxes charged on imports from the EU.

One way of addressing net welfare losses related to employment displacement is to undertake production and employment adjustment programmes, as well as skill development and productivity enhancement programmes. Support for such programmes should be negotiated with the EU.

To sustain the regional traded products and markets, all the traded products among countries of the sub-region that result to greater trade diversion as opposed to trade creation should be excluded from tariff removal during EPAs negotiations. These would facilitate reallocation of labour into expanding production sectors.

\section{ACKNOWLEDGEMENTS}

This paper forms part of the authors" on-going research work with the African Economic Research Consortium (AERC) Nairobi, Kenya. The authors are grateful to the consortium for providing financial and technical support during data sourcing and analysis.

\section{REFERENCES}

[1] ACP Secretariat (2002) "ACP Guidelines for the negotiations of Economic Partnership Agreements". ACP/61/056/02 [Final]. Brussels, 5 July, available online at http:www.acpsec.org/en/epa/index.htm 10 July 2005.

[2] Andrew McKay, A., C. Milner, and O. Morrissey (2005) "Some Simple Analytics of the trade and welfare effects of Economic Partnership Agreements". Journal of African Economies, 14(3): 327-58.

[3] Chris Milner, Oliver Morrissey and Evious zgovu Research Papers at www.nottingham.ac.uk/economics/credit/ No.07/09; 00/8.

[4] Dion, D.P. (2004), "Regional Integration and Economic Development: ATheoretical Approach",. Mimeo, Mannhein University. 
[5] European Centre for Development Policy Management (ecdpm) http://www.ecdpm.org.

[6] ECOWAS Statistical Bulletin (2008) A Publication of The Executive Secretariat, Abuja, Nigeria. Statistical Annex 67-71.

[7] ECOWAS Handbook on international Trade (2008) A Publication of The Executive Secretariat, Abuja, Nigeria. Page 15.

[8] G. O. Onogwu, C. J. Arene, and A. N. Chidebelu (2011) "An Analysis of Trend and Determinants of Intra-ECOWAS Trade in Agricultural Products" Indian Journal of Economics and Business, Vol. 10, No. 4, Pp. 553-570.

[9] Oyejide, T. A. (2005) "Negotiations and Aid for Trade: West African Perspectives and Priorities" A Draft Report submitted to ILEAP, Canada.

[10] Panagariya, A. (1998), Rethinking the new Regionalism" Paper Presented at the UNDP-World Bank Trade Expansion Conference, The World Bank, Washington, D. C. January.

[11] Panagariya, A. (2002), "EU preferential Trade Agreements and Developing Countries, World Economy, 25(10), pp 1415-32.

[12] UN COMTRADE Data; Result Available online at https://www.wits.worldbank.org.

[13] UNCTAD TRAINS Tariff \& other Data; Result Available online at https://www.wits. worldbank.org. 